\title{
An analytical study on theme choices in the academic essays of Libyan EFL undergraduate students
}

\section{Zainab Khalifa Khalafallah Khalifa ${ }^{1}$}

Faculty of Arts - University of Sirte

Received: 23-11-2020 Accepted: 12-12-2020 Available Online 30 -12-2020

https://doi.org/10.36602/faj.2020.n16.07

\section{Abstract}

Theme is the element which a speaker or writer chooses as a point of departure for a clause. Theme is of different types; each of which has a certain function in the overall discourse. Choosing the appropriate theme is important to deliver the intended message of the discourse. Many EFL students encounter problems in their theme choice which might decrease the quality of their written products. The current study investigated the frequency of the different types of themes to find out the most dominantly used theme types. For data collection, 15 academic essays written by advanced semesters' students were utilized to fulfill the purpose of the study. In analyzing the written texts, the Halladian Analysis System was followed to categorize the type of themes used in the students' writings. According to the study findings, the Topical Unmarked theme was highly dominant in the students' writing. The Textual themes occupied the second place in the frequency of use. Not surprisingly, the Interpersonal theme was very rare in the students' essays. The results of the study were interpreted and contextualized within the existing body of literature. Finally, the implications and limitations of the study were discussed.

Key words: Topical theme, Textual themes, Interpersonal theme, theme choices, academic writing.

zainabderibash@su.edu.ly ${ }^{1}$ 


\title{
دراسة تحليلية لأنواع المبتدأ المستخدمة في المقالات الأكاديمية للطلاب الليبيين الدارسين للغة الإنجليزية كلغة أجنبية
}

\author{
زينب خليفة خلف الله خليفة$$
\text { كلية الآداب - جامعة سرت }
$$

ملخص البحث

المبتدأ هو العنصر الذي يختاره المتحدث أو الكاتب كبداية للجملة. و هناك عدة أنواع للمبتدأ وكل منها يؤدي وظيفة معينة في الخطاب العام. و يعتبر اختيار المبتدأ الصحيح مهما لإيصال الرسالة المقصودة للخطاب. يواجه الكثير من طلاب اللغة الإنجليزية كلغة أجنبية مشاكل في اختيار المبتدأ الصحيح و الذي بدوره يقلل من جودة كتاباقم. بناء على ذلك، بحثث الدراسة الحالية أنواع المبتدأ الأكثر استخداما من قبل الطلاب في كتاباقم. ولغرض جمع البيانات المطلوبة، تح تحليل 15 عينة مقالية مكتوبة، و تم تحليل النصوص وتحديد أنواع المبتدأ في ضوء نظام Halliday لتصنيف أنواع المبتدأ. و قد توصلت الدراسة إلى عدة نتائج منها أن نوع مبتدأ Unmarked Topical هو النوع الأكثر استخداما في كتابات الطلاب، ويحتل نوع المبتدأ Textual المرتبة الثانية من حيث تكرار الاستخدام. ومن النتائج المتوقعة أن النوع الثالث Interpersonal Theme هو نوع المبتدأ الأقل استخداما في كتابات الطلاب، وقد تمت مناقشة نتائج الدراسة ومقارنتها بنتائج الدراسات السابقة. وتم أيضا مناقشة بعض قيود الدراسة الحالية وبعض المقترحات المتعلقة بنتائج الدراسة.

الكلمات المفتاحية: الكتابة الأكاديمية، المبتدأ في اللغة الإنجليزية، أنواع المبتدأ. 


\section{Introduction}

\subsection{The concept of Theme and Rheme}

The theme system is an obvious representation of the language textual metafunction. Theme is the primary constituent in a clause as message (Panggabean, 2011). "One of the constraints on speakers/ writers when producing their message is that they can produce only one word at a time" (Belmonte \& McCabe-Hidalgo, 1998, p. 15). Choosing the beginning point for the utterance is of a paramount importance in structuring meaning. The starting point is very significant in discourse and particularly when producing a clause (Belmonte \& McCabe-Hidalgo, 1998). "Whatever is chosen to be in first place will influence the hearer's/ reader's interpretation of everything that comes next in the discourse since it will constitute the initial textual context for everything that follows" ( Belmonte \& McCabe-Hidalgo, 1998, p. 15).

According to Halliday and Matthiessen, (2014), any clause spoken or written, carries a message 'a quantum of information'; it is the constituent in a clause which is selected by the speaker for 'grounding' what he/she intends to say. The theme element is one part of a clause. To fulfill the function of a message, a theme needs to combine with the remainder of the clause (Halliday and Matthiessen, 2014). According to Halliday and Mattheissen (2004), as defined by the Prague School of linguistics:

Theme is the element which serves as the point of departure of the message, it is that which locates and orients the clause within its context. The remainder of the message; the part in which the theme is developed, is called in Prague School terminology, the Rheme (p. 64)

In words of Fries, (1995), "the theme functions as an orienter to the message. It orients the listener/reader to the message that is about to be perceived and provides a framework for the interpretation of the 
message" (p. 318). As described by Wang (2007), "Theme and Rheme are two terms which represent the way in which information is distributed in a sentence" (p. 166). For illustration, the following examples make clear the picture of sentences organized in the light of theme and Rheme structure (Adopted from Wang 2007):

Table 1: Examples of Theme-Rheme structure

\begin{tabular}{|l|l|}
\hline \multicolumn{1}{|c|}{ Theme } & \multicolumn{1}{c|}{ Rheme } \\
\hline The lion & beat the unicorn all-round the town \\
\hline All round the town & the lion beat the unicorn \\
\hline However, the unicorn & still did not want to bow to the lion \\
\hline The lion & decided to beat him to death \\
\hline
\end{tabular}

In this vein, it is important to highlight the notion of new and given information in relation to theme and rheme. In the words of Wang (2007):

In cohesive writing, 'given' information in a clause needs be presented in theme position, which acts like a signpost signaling a reader where the meanings have come from and where they are going to. The new information needs to be located in Rheme position (p. 167)

\subsection{Halliday's categorization of theme}

Halliday (1985, pp. 40-56) classified themes in to the following types (as cited in Jalilifar, 2010b, p. 12):

1. Textual themes: conjunctions, conjunctive adjuncts, and continuatives.

2. Interpersonal themes: modal adjuncts, finite operators, and imperative let's.

3. Marked themes: adverbial groups, prepositional phrases, and complements which are nominal groups that are not functioning as subjects.

4. Unmarked themes: participants (subjects), extra position (it), existential (there), thematic equatives (e.g., what is important now 
is to analyze the results), processes [ verbs], and WH- elements in interrogatives.

5. Simple themes e.g., I went to London last week.

6. Multiple themes.

The following will be an illustration of each of the above types plus an additional Topical theme as named by Halliday in later editions.

The topical theme includes marked and unmarked themes (Nichmah, 2010). Topical theme is the 'ideational' stage of the theme. It is the element that occupies the initial position of the clause expressing a 'representational' meaning of some kind (Panggabean, 2011). Topical theme is the element which functions within the transitivity system of the clause (Panggabean, 2011). Any process consists of three components: (1) the participants [subjects] in the process (2) the process itself [action] (3) the circumstantial elements that express time, manner, and cause of the process (Halliday \& Matthiessen, 2014, p. 105). When any of these elements is given a transitivity role and put in an initial position in the clause, this element is described as topical theme (Eggins, 2004). To exemplify;

\section{- a participant can be a topical theme as in;}

Charles Dickens was famous for his first novel 'Oliver Twist'.

- Or a circumstance as in;

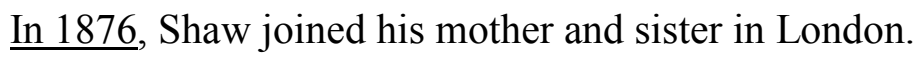

Adopted from Panggabean (2011)

- Or a process as in; Forget it I never shall. [used commonly in spoken English] Adopted from Halliday and Matheissen (2004)

The second type of theme is the textual theme which is illustrated in the following tables: 
Table 2: Types of Textual theme

\begin{tabular}{|c|c|c|}
\hline \multirow{3}{*}{ Textual } & Continuative & yes, no, well, oh, now \\
\hline & $\begin{array}{c}\text { conjunction } \\
\text { (structural } \\
\text { Theme) }\end{array}$ & $\begin{array}{l}\text { Among the most common are: } \\
\text { (paratactic): and, or, nor, either, neither, but, } \\
\text { yet, so, then, for } \\
\text { (hypotactic): when, while, before, after, until } \\
\text {, because, if, although, unless, since, that, } \\
\text { whether to, by, with, despite, as, even, if, } \\
\text { in case, supposing (that), assuming (that), } \\
\text { given that, provided (that), so that, so as to, } \\
\text { in order to, in the event that, in spite of the } \\
\text { fact that }\end{array}$ \\
\hline & conjunctive $\mathrm{A}$ & \\
\hline
\end{tabular}

Adopted from Halliday and Matthiessen (2004, p. 81)

Table 3: Conjunctive adjuncts

\begin{tabular}{|c|c|c|c|}
\hline & & Meaning & Example \\
\hline \multirow{5}{*}{ I } & Appositive & i.e., e.g. & that is, in other words, for instance \\
\hline & Corrective & rather & or rather, at least, to be precise \\
\hline & Dismissive & $\begin{array}{ll}\text { in any } \\
\text { case }\end{array}$ & in any case, anyway, leaving that aside \\
\hline & Summative & in short & briefly, to sum up, in conclusion \\
\hline & Verificative & actually & actually, in fact, as a matter of fact \\
\hline \multirow{3}{*}{ II } & Additive & and & also, moreover, in addition, besides \\
\hline & Adversative & but & on the other hand, however, conversely \\
\hline & Variative & instead & instead, alternatively \\
\hline \multirow{6}{*}{ III } & Temporal & then & $\begin{array}{l}\text { meanwhile, before that, later on, next, } \\
\text { soon, finally }\end{array}$ \\
\hline & Comparative & likewise & likewise, in the same way \\
\hline & Causal & So & $\begin{array}{l}\text { therefore, for this reason, as a result, } \\
\text { with this in mind }\end{array}$ \\
\hline & Conditional & (if...) then & $\begin{array}{l}\text { in that case, under the circumstances, } \\
\text { otherwise }\end{array}$ \\
\hline & Concessive & yet & nevertheless, despite that \\
\hline & Respective & as to that & in this respect, as far as that's concerned \\
\hline
\end{tabular}

The third type of theme is Interpersonal which includes the following elements: 
Table 4: Interpersonal theme types

\begin{tabular}{|l|l|}
\hline \multirow{3}{*}{ Interpersonal } & modal or comment Adjunct (modal theme) \\
\cline { 2 - 2 } & vocative \\
\cline { 2 - 2 } & finite verbal operator (in yes/no interrogative) \\
\hline & Adopted from Halliday and Matthiessen $(2004$, p. 81$)$
\end{tabular}

One kind of constituent that is likely to be chosen as interpersonal theme is modal adjuncts. Examples are listed in the following table:

Table 5: Modal adjuncts types

\begin{tabular}{|l|l|l|}
\hline \multicolumn{1}{|c|}{ Type } & \multicolumn{1}{|c|}{ Meaning } & \multicolumn{1}{c|}{ Examples } \\
\hline Probability & how likely? & $\begin{array}{l}\text { probably, possibly, certainly, perhaps, } \\
\text { maybe }\end{array}$ \\
\hline Usuality & how often? & $\begin{array}{l}\text { usually, sometimes, always, (n)ever, } \\
\text { often, seldom }\end{array}$ \\
\hline Typicality & how typical? & $\begin{array}{l}\text { occasionally, generally, regularly, for } \\
\text { the most part }\end{array}$ \\
\hline Obviousness & how obvious? & of course, surely, obviously, clearly \\
\hline Opinion & I think & in my opinion, personally, to my mind \\
\hline Admission & I admit & frankly, to be honest, to tell you the truth \\
\hline Persuasion & I assure you & honestly, really, believe me, seriously \\
\hline Entreaty & I request you & please, kindly \\
\hline presumption & I presume & $\begin{array}{l}\text { evidently, apparently, no doubt, } \\
\text { presumably }\end{array}$ \\
\hline Desirability & how desirable? & $\begin{array}{l}\text { (un)fortunately, to my delight/distress, } \\
\text { regrettably, hopefully }\end{array}$ \\
\hline Reservation & how reliable? & $\begin{array}{l}\text { at first, tentatively, provisionally, } \\
\text { looking back on it }\end{array}$ \\
\hline Validation & how valid? & $\begin{array}{l}\text { broadly speaking, in general, on the } \\
\text { whole, strictly speaking, in principle }\end{array}$ \\
\hline Evaluation & how sensible? & $\begin{array}{l}\text { (un)wisely, understandably, mistakenly, } \\
\text { foolishly }\end{array}$ \\
\hline Prediction & how expected? & $\begin{array}{l}\text { to my surprise, surprisingly, as expected, } \\
\text { by chance }\end{array}$ \\
\hline
\end{tabular}

Adopted from Halliday and Matthiessen (2004, p. 82)

An additional kind of interpersonal theme is the Finite. A finite theme is the auxiliary verb when given a prominence and put first in a 
yes-no interrogative clause. The finite verbal operator such as 'is, isn't, does, doesn't, do, don't, can, can't, etc. are elements which are put first to function as a theme along with the subject of the clause (Panggabean, 2011). The following example illustrates:

Table 6: Finite as an Interpersonal theme

\begin{tabular}{|l|l|l|}
\hline Can & You & come early tomorrow? \\
\hline Did & you' & see him? \\
\hline Theme 1 Interpersonal & Theme 2 Topical & Rheme \\
\hline
\end{tabular}

Another possible element to function as interpersonal theme is the vocatives. A vocative is "names or other forms of direct address such as 'darling" (Thompson, 2013). For instance:

Table 7: Vocative as an Interpersonal theme

\begin{tabular}{|l|l|l|}
\hline Goerge, & the book & was amazing \\
\hline Theme 1 Interpersonal & Theme 2 Topical & Rheme \\
\hline
\end{tabular}

\subsubsection{Marked and unmarked theme}

According to Halliday and Matthiessen (2004), the theme mapping onto the subject in declarative clauses is referred to as 'unmarked theme'. Thus, the subject is chosen as an initial element-as a theme- unless a speaker or a writer has another reason to choose something else.

\section{Table 8: Unmarked theme- Subject}

\begin{tabular}{|l|l|}
\hline They & visited the place \\
\hline Unmarked Theme/Subject & Rheme \\
\hline
\end{tabular}

In daily conversations, ' $\mathrm{I}$ ' as a pronoun is widely used as unmarked theme particularly in declarative clauses (Halliday and Matthiessen, 2004). This is because "much of our talk consists of messages concerned with ourselves, and especially with what we think and feel" (Halliday and Matthiessen, 2004, p. 73).

Next to 'I', other personal pronouns; it, he, she, we, you, they and it (impersonal pronoun) come in the unmarked theme position. Then, the nominal group- whose head is a proper or a common noun- and 
nomalization are other elements to function as Subject/ unmarked theme (Halliday and Matthiessen, 2004).

On the other hand, when the theme is not the subject in declarative clauses, it is a marked theme. To exemplify this, the following table illustrates:

\section{Table 9: Marked theme not subject}

\begin{tabular}{|l|l|l|}
\hline Someday & "they & 'll realize the truth" \\
\hline & Subject & \\
\hline Marked theme & Rheme & \\
\hline
\end{tabular}

(Adopted from Panggabean, 2011)

Usually, the marked theme is either a prepositional phrase as in ' in the corner' or ' at night' etc. which is functioning as an adjunct or an adverbial group like 'today',' somewhat distractedly' etc. Besides, but infrequently, complements might also be thematic. A complement is "a nominal group that is not functioning as a subject- something that could have been a subject but is not" (Halliday and Matthiessen, 2004, p. 73). An example for this is; ' that they don't tell us', ' you I blame for this' (Halliday and Matthiessen, 2004).

The following table illustrates the marked and unmarked theme in declarative clauses:

Table 10: Theme-Rheme boundary (\#)

\begin{tabular}{|c|c|c|c|}
\hline & Function & Class & Clause example \\
\hline \multirow{7}{*}{$\begin{array}{l}\text { Unmarked } \\
\text { Theme }\end{array}$} & \multirow{7}{*}{ Subject } & \multirow{3}{*}{$\begin{array}{c}\text { Nominal group: } \\
\text { pronoun as } \\
\text { head }\end{array}$} & I \# had a little nut-tree \\
\hline & & & she \# went to the baker's \\
\hline & & & $\begin{array}{l}\text { there \# were three jovial } \\
\text { Welshmen }\end{array}$ \\
\hline & & \multirow{3}{*}{$\begin{array}{c}\text { Nominal group: } \\
\text { common or } \\
\text { proper noun as } \\
\text { head }\end{array}$} & $\begin{array}{l}\text { a wise old owl \# lived in an } \\
\text { oak }\end{array}$ \\
\hline & & & Mary \# had a little lamb \\
\hline & & & $\begin{array}{l}\text { London Bridge \# is fallen } \\
\text { down }\end{array}$ \\
\hline & & Nominalization & $\begin{array}{l}\text { what I want } \# \text { is a proper } \\
\text { cup of coffee }\end{array}$ \\
\hline & Adjunct & Adverbial group & merrily \# we roll along \\
\hline
\end{tabular}




\begin{tabular}{|c|c|c|c|}
\hline \multirow{6}{*}{$\begin{array}{l}\text { Marked } \\
\text { Theme }\end{array}$} & & $\begin{array}{l}\text { Prepositional } \\
\text { phrase }\end{array}$ & $\begin{array}{l}\text { on Saturday night \# I lost } \\
\text { my wife }\end{array}$ \\
\hline & \multirow{5}{*}{ 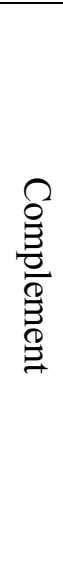 } & \multirow{2}{*}{$\begin{array}{l}\text { Nominal group: } \\
\text { common or } \\
\text { proper noun as } \\
\text { head }\end{array}$} & $\begin{array}{l}\text { a bag-pudding \# the King } \\
\text { did make }\end{array}$ \\
\hline & & & $\begin{array}{l}\text { Eliot \# you're particularly } \\
\text { fond of }\end{array}$ \\
\hline & & \multirow[t]{2}{*}{$\begin{array}{l}\text { Nominal group: } \\
\text { pronoun as head }\end{array}$} & $\begin{array}{l}\text { all this \# we owe both to } \\
\text { ourselves and to the peoples } \\
\text { of the world [ who are so } \\
\text { well represented here } \\
\text { today] }\end{array}$ \\
\hline & & & this \# they should refuse \\
\hline & & Nominalization & $\begin{array}{l}\text { what they could not eat that } \\
\text { night \# the Queen next } \\
\text { morning fried }\end{array}$ \\
\hline
\end{tabular}

Adopted from Haliday and Matthiessen (2004, p. 47)

Above all, as explained by Halliday (1994), a simple theme is the theme of the clause that "consists of just only one structural element, and that is represented by just one unit, one prepositional phrase, nominal group or adverbial group" (p. 39). Moreover, as defined by Halliday (1994), a multiple theme is a topical theme with any other element that precedes it in the clause (as cited in Kang, 2016). The multiple theme "extends from the beginning of the clause up to the first element that has a function in transitivity, which means that the last constituent in a multiple theme has to be an experiential or topical theme. The element that comes before the topical theme can vary from elements which are textual and /or interpersonal in function" (Kang, 2016, p. 1055).

\section{Table 11: An example of multiple themes}

\begin{tabular}{|l|l|c|}
\hline Nevertheless & he & can reflect on his own experience \\
\hline Theme 1 & Theme 2 & Rheme \\
\cline { 1 - 2 } Textual & Topical & \\
\hline \multicolumn{2}{|c|}{ Multiple theme } & \\
\hline
\end{tabular}




\subsubsection{Theme in non-declarative clauses}

The other main types of clauses are interrogatives and imperatives. The typical function of an interrogative is to find out the missing information (Thompson, 2013). Wh-interrogative is a clause which requires addressing a certain answer (information) (Panggabean, 2011). The wh-element is "the group or phrase in which the wh-word occurs" (Panggabean, 2011, p. 50).

The wh-word or group is an element which represents this missing information that is required from someone to provide (Thompson, 2013). This wh-element is functioning as theme of the clause (Panggabean, 2011). "The clause structure of WH-questions has evolved as different from that of declaratives precisely in order to allow the thematization of the WH-element" (Thompson, 2013, p. 150). The following are examples of theme and rheme division in whinterrogatives:

Table 12: Examples of theme and rheme division in wh-interrogatives:

\begin{tabular}{|l|l|}
\hline Who & Witnessed the event? \\
\hline Which dish & Do you prefer? \\
\hline What & did you notice there? \\
\hline How often & do you go there? \\
\hline Theme & Rheme \\
\hline
\end{tabular}

It is typical to find a wh-element at the beginning of an interrogative clause. This is the unmarked choice. But still the makedness choice is possible to occur if the wh-element is delayed from its initial place to allow another element to come first. The marked choice of wh-element theme is not uncommon, as bringing the wh-element at first position is specifically natural in discourse (Thompson, 2013). The following are examples of the marked choice of themes:

Table 14: An example of marked theme of wh- element

\begin{tabular}{|l|l|}
\hline During the journey & where did you go? \\
\hline Theme & Rheme \\
\hline
\end{tabular}

The other non-declarative clause is the imperative. It is a clause whose message is either "I want you to do something" or "I want us 
'you and me' to do something". The former purpose is expressed by using the verb itself as a natural starting point whereas the latter is expressed by using the word 'let's'. In the first type, the 'you' can be explicitly put as a theme as in; 'you keep quiet' which is the untypical form of the imperative while 'keep quiet', in which the verb is thematic, is simply the typical choice (Panggabean, 2011).

Table 15: Examples of themes in imperatives

\begin{tabular}{|l|l|}
\hline Keep & quiet \\
\hline Marked Theme & Rheme \\
\hline You & keep quiet \\
\hline Unmarked Theme & Rheme \\
\hline
\end{tabular}

\subsection{Research problem}

Without coherence, a text is only a collection of words, sentences and structures that are disjoined because it lacks the discourse links. As reported by Sherman, Slowdown, Whiton and Wiemelt (2011), incoherent text inhibits the readers to track the passage flow appropriately and will lead to misunderstanding of the meaning and the main points. Coherence gives directions to readers to move smoothly through ideas, sentences and paragraphs (as cited in Adawiyah, 2017). Accordingly, coherence in writing is an element of a paramount importance and should be given significant attention by writers to formulate appropriately written texts and deliver the intended message.

EFL learners are encountering several problems in their academic writing. One of these difficulties is how to maintain coherence and cohesion, which decreases the quality of their performance and examination scores. Failure to keep the thematic fitness between the threads of the text is predicted to be one reason behind the lack of coherence in writing (Jalilifar, 2010a).

There are three basic theme types which are Topical theme, Textual theme, and Interpersonal theme. Each of these types has a discourse function that contributes essentially to the quality of the written text. Topical theme contributes to identifying the focus of the 
clause. Textual theme plays a significant role in providing a sense of coherence to the written product. Interpersonal theme helps to show the writers' voice and stance within the written text. The researcher of the current study, as a teacher of English writing, observed that students often rely on topical themes, which is an impact of the fact that an English sentence typically starts with a subject. Accordingly, the students' use of other types of themes is not balanced in a way that achieves coherence and qualifies the written texts as well-written. For this reason, this study attempted to explore the frequency of the different types of themes to highlight the most and less dominant of these types. The identification of this issue will lead to a number of suggestion and implications that are worth considering by practitioners in the field.

\subsection{Research questions}

The study attempted to answer the following questions:

1. Which of the three basic theme types; Topical theme, Textual theme, and Interpersonal theme, is the most frequently used by the students in their academic essays?

2. Which are the most frequent themes used by the students, simple or multiple themes?

3. Which are the most frequent themes used by the students, marked or unmarked themes?

\subsection{Research objectives}

The study aimed to identify :

1.The students' frequent choices of theme types in their academic essays.

2.The frequency of Simple and Multiple themes in the students' academic essays

3.The frequency of Marked and Unmarked themes in the students' academic essays 


\section{Related studies}

The areas of theme types and choices were highly investigated by researchers. Zha (2019) conducted a study in Singapore to investigate the students' choices of marked themes in their writing. He aimed to find out which marked themes are mostly used and which ones are overused or misused. A number of students' written samples were analyzed in order to fulfill the research aims. It was concluded that the most popular marked theme used by the students was "however" which the students most frequently misused.

In the same vein, Yuned (2016) investigated the most dominantly used themes in 2015 TEFLIN (Teaching English as Foreign Language in Indonesia) abstracts produced by non-native speakers of English. The writers of the abstracts were Indonesian speakers. It was found that topical themes were the most used type of themes in the written abstracts. Then, it was the textual theme which occupied the second place of use. Additionally, only few interpersonal themes were used by the writers.

Moreover, Ridha (2014) conducted a research in Albasra university- department of English. He examined different dimensions on thematization in students' academic writing. One of these aspects was to explore the frequency of theme types in the students' writings. For the purpose of the study, he analyzed eighty written compositions and essays. According to the results, the most frequently used type of theme was the unmarked themes which were dominant in the students' writings. Besides, the topical theme 'nominal group' had the highest percentage of use.

A further study was conducted by Gunawan and Aziza (2017). The study attempted to investigate the theme choices used by the writer in a good undergraduate thesis in an Indonesian university. The study was a case study in which a descriptive-qualitative research design was used. The data was analyzed in the light of the Hallidayian theme system. In terms of theme choices, the findings reported that 
the three types of theme; topical, interpersonal, textual were used in the thesis. The topical themes used were marked and unmarked. The interpersonal themes used included using unmodulated clauses, comment adjuncts, mood adjuncts and modal operators. Further, coordination, subordination, conjunctive adjuncts and relative pronouns were the textual themes mostly employed in the thesis. More significantly, while the topical themes were the most dominant in the thesis, interpersonal themes were the rarest type used in the thesis. Still, the frequency of textual themes was more than the interpersonal themes.

Jalilifar (2010a) investigated the frequency of theme types and made an analysis of thematization used in students' compositions. The study population was ninety students from Shahid German University. For data analysis, Halliday's and McCabe thematicity models were followed. The conclusions emphasized that the students relied more on textual themes. The frequency of unmarked themes was more than marked themes which indicated the occupation of topical themes to the thematic and subject positions. Moreover, in the students' writings, the interpersonal theme was underestimated.

Additionally, Ibrahimi (2016) conducted a study to investigate the theme types and patterns used in research article abstracts. 120 abstracts from different disciplines; Applied Linguistics, Applied Physics, Agriculture and Economics, were analyzed. The data were analyzed in light of the Halliday's (1994) thematic organization model and Eggin's (2004) thematic progression model. It was concluded that the unmarked topical themes were used more frequently than marked topical themes. This indicated the simple structure nature of the written abstracts. Further, the interpersonal themes were less used and less preferred than the textual themes. "The lack of Interpersonal themes affirmed the argumentative nature and impersonal tone of the RA [Research Article] abstract genre" (Ibrahimi, 2016, p. 108). The frequent textual themes used were additive, time, cause, contrastive. 
Besides, simple themes were used more extensively than multiple themes.

\section{Methodology}

\subsection{Research design}

The data of the study was derived from the students' written corpus. The written samples were argumentative and compare and contrast essays written by the students for their assignments and homework. The samples were 15 essays collected by me, as a teacher of writing in the department of English at the University of Sirte. The students' samples were collected during different courses of advanced writing. The research design was quantitative as the theme types were counted and the frequency percentages of each theme type were estimated and then conclusions were drawn.

\subsection{Population and sample}

15 students' written samples were analyzed for the purpose of the study. The writers of the used samples were undergraduate university students studying in the department of English at the University of Sirte. The writing samples were collected during different modules of advanced writing course.

\subsection{Instrumentation and data collection}

The data of the study was the students' written samples collected during various advanced writing modules in the department of English at the University of Sirte. The following are the procedures followed in designing the study:

1. Dividing all sentences into clauses.

2. Rewriting and labeling the parts of the clause based on thematic structure.

3. Identifying theme types in the written texts.

4. Carrying out quantative analyses.

5. Drawing conclusions. 


\section{Results}

In the following section, the frequency analysis of the theme types used by the students in their writings are presented and discussed.

Table 15: The frequency analysis of the three basic theme types

\begin{tabular}{|l|c|c|}
\hline \multicolumn{1}{|c|}{ Theme type } & Frequency & Percentage \\
\hline Topical Theme & 395 & $62.30 \%$ \\
\hline Textual Theme & 224 & $35.33 \%$ \\
\hline Interpersonal Theme & 15 & $2.36 \%$ \\
\hline Total & \multicolumn{2}{|c|}{634} \\
\hline
\end{tabular}

The above table reveals the frequency analysis of occurrence of the three basic types of themes; topical, textual and interpersonal themes used by the students. The total number of the themes used was 634. The topical theme type was the highest in the frequency of use, then, it was the textual themes, followed by the interpersonal themes which occupied the lowest rate of use in the students' writings.

\subsection{Frequency analysis of topical theme}

\section{Table 16: The frequency analysis of the Topical theme types}

\begin{tabular}{|c|c|c|c|}
\hline Topical theme types & Frequency & Percentage & \multirow{10}{*}{ 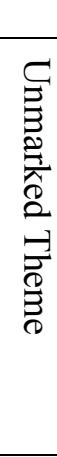 } \\
\hline Noun Phrases (nominals) & 199 & $50.37 \%$ & \\
\hline Pronouns (nominals) & 115 & $29.11 \%$ & \\
\hline Nominal Group Complex (subject) & 15 & $4.05 \%$ & \\
\hline Wh element & 1 & $0.25 \%$ & \\
\hline Phrasal Verbs (process) & 1 & $0.25 \%$ & \\
\hline Total of Unmarked themes & 331 & $83.79 \%$ & \\
\hline Prepositional Phrase & 52 & $13.16 \%$ & \\
\hline Adverbial Phrase & 10 & $2.53 \%$ & \\
\hline Adjective Phrases & 1 & $0.25 \%$ & \\
\hline Nominal Group Complex (not subject) & 1 & $0.25 \%$ & \\
\hline Total of Marked themes & 64 & $16 \%$ & \\
\hline Overall Total & 395 & & \\
\hline
\end{tabular}

Looking back on the frequency analysis of the topical themes in table 16, it is obvious that majority of Topical themes were marked themes which occupied the position of the subjects. The marked themes used were realized by nominals (noun phrases) and pronouns. 
The second frequent type of topical theme used by the students was marked theme realized by the prepositional phrases which occupied the rate of $13 \%$.

\subsection{Frequency analysis of textual theme}

\section{Table 17: The frequency analysis of the Textual theme type}

\begin{tabular}{|l|c|c|}
\hline Textual theme types & Frequency & Percentage \\
\hline Conjunctions & 145 & $64.73 \%$ \\
\hline Conjunctive Adjunct & 79 & $35.26 \%$ \\
\hline \multicolumn{1}{|c|}{ Total } & 224 & \\
\hline
\end{tabular}

According to the frequency analysis of the textual theme types used in the students' writings, the textual themes used 224 times out of the 634 themes found in the students' writings. The highest portion of textual themes was conjunctions estimated at $64 \%$ of the total Textual themes. Moreover, the other type of textual themes used was conjunctive adjuncts at a percentage of $35 \%$.

\subsection{Frequency analysis of interpersonal themes}

Table 18: The frequency analysis of the interpersonal theme

\begin{tabular}{|l|c|c|}
\hline Interpersonal theme type & Frequency & Percentage \\
\hline Modal/ Comment Adjunct & 14 & $93.33 \%$ \\
\hline Finite Verbal Operator & 1 & $6.66 \%$ \\
\hline Total & \multicolumn{2}{|c|}{15} \\
\hline
\end{tabular}

\subsection{Frequency analysis of simple and multiple themes}

Table 19: The frequency analysis of the simple and multiple themes

\begin{tabular}{|l|c|c|}
\hline Theme type & Frequency & Percentage \\
\hline Simple themes & 190 & $48.10 \%$ \\
\hline Multiple themes & 205 & $51.89 \%$ \\
\hline
\end{tabular}

A simple theme is the theme which only includes one element (topical theme) whereas multiple themes are the themes in which topical theme does mainly exist in the multiple constituent except one type as shown in the table 20 . 
As displayed in table 19, the multiple themes overweighed the number of simple themes used in the student's essays. Nearly $52 \%$ of the totals were multiple themes.

\subsection{Frequency analysis of multiple themes}

\section{Table 20: The frequency analysis of the multiple themes}

\begin{tabular}{|l|c|r|}
\hline Textual theme Types & Frequency & Percentage \\
\hline Textual + Topical & 172 & $83.90 \%$ \\
\hline Topical + Textual & 8 & $3.90 \%$ \\
\hline Interpersonal + Topical & 8 & $3.90 \%$ \\
\hline Textual + Textual + Topical & 7 & $3.41 \%$ \\
\hline Textual + Topical + Interpersonal & 3 & $1.46 \%$ \\
\hline Textual + Textual & 2 & $0.97 \%$ \\
\hline Textual + Interpersonal + Topical & 2 & $0.97 \%$ \\
\hline Topical + Interpersonal & 2 & $0.97 \%$ \\
\hline Textual + Textual + Textual + Topical & 1 & $0.48 \%$ \\
\hline Total & \multicolumn{2}{|c|}{205} \\
\hline
\end{tabular}

Table 20 illustrates the frequency analysis of different types of the multiple themes found in the students' writings. Textual+Topical theme was the most dominant type used by the students. The rate for this type exceeded $83 \%$ of the total number of multiple themes found in the analyzed texts. The other types of multiple themes were used by the students at very low percentages. Veritably, the other types of multiple theme appeared in descending order of use as table 20 illustrated.

\section{Discussion}

On the whole, the three basic types of theme; topical, textual, and interpersonal themes were used by the students in their writings but in different rates of occurrence. The topical theme was the most dominant theme type in the students' compositions. This result is in line with the findings of Yuned (2016) and Gunawan and Aziza (2017). Yuned (2016) reported that the dominant use of topical themes might reflect the writer's feeling that a clear way to describe the focus in a sentence is to locate a topical theme particularly in the position of 
a participant (subject). Obviously, by putting the topical theme at the start of a sentence, the reader is clearly informed of the sentence subject.

Moreover, the analysis results indicated that the frequency of unmarked topical themes was extensively higher than the marked topical themes. The estimated percentage of unmarked topical themes exceeded $83 \%$ while the marked topical themes were only used in a low rate of $16 \%$. This result is similar to the study's finding of Ebrahimi (2016) who highlighted that the more frequent use of the unmarked topical themes indicates the simple structure of the written compositions. Besides, students tend to frequently use unmarked topical themes because "topical themes are obligatory and they are choices that students must write in the text. They are the grammatical subjects which students use to fill in the participant roles in the text through the realization of nominal groups (noun phrases and pronouns)" (Choo, 2009, p. 103). Halliday (2004) explained that the students tend to use the unmarked theme if "there is no prior context leading up to it, and no positive reason for choosing anything else" (p.58). Strictly speaking, this reason might be one possible interpretation for the students' heavy reliance on the nominals as themes in most of their clauses. In the same line of discussion, Arunsirot (2013) interpreted that many students generally struggle in producing good texts and the simplest way to produce grammatically appropriate sentences is to start them with nominals; noun phrases, pronouns or nominal group complexes as subjects.

It is not surprising for the textual theme to be used more than interpersonal themes. Arunsirot (2013) gave an explanation for this by reporting that

Since this theme not only acts as a connection which links the relationship of the clause within the text but also provides more explicit guidance to the reader on how to obtain a coherent 
interpretation of the text, this may result in finding it more frequently than the interpersonal element (pp. 171-172).

Above all, in the analyzed texts, the textual elements were realized by the use of subordinating and coordinating conjunctions and conjunctive Adjuncts. The use of variety of cohesive ties is an indication of the students' attempt to generate coherence within their written texts (Eggins, 2004 as cited in Gunawan and Aziza, 2017).

As expected, the interpersonal themes were the lowest in the frequency of use. Only 15 items were used as interpersonal themes. 14 of them were modal/comment adjuncts and only one finite verbal operator occupied the position of interpersonal themes in the analyzed texts.

For the interpersonal themes, it was clear that this theme type was the rarest in the students' writings. This result correlated with Jalilifar's (2010a) finding. The underestimation of interpersonal themes suggests a factual tone in the students' writing thereby decreasing the degree of personality within the written productions which resulted in a less-reader friendly writing (Jalilifar, 2010a).

Additionally, the simple themes were less frequent than the multiple themes. This result is opposite to the finding reached by Jalilifar (2010a) in which he concluded that "multiple themes allow writers to encode coherence markers whereas their low proportion in students' writings might reduce continuity and their failure to persuade the reader to read" (p. 37). It could be said that good use of multiple themes is an indication of the students' ability to persuade the reader of their arguments in the written texts.

In the light of the most frequent multiple theme, the students of the current study had a greater tendency to use the textual + topical multiple themes. Jalilifar (2010a) explained that

The tendency of learners toward textual + topical pattern marks the structural dominance over the interpersonal features. This 
decision may also amount to the formality and factuality involved in students' writing. The native speaker used interpersonal + topical theme comparatively more frequently, and textual + topical theme, though still dominant, was of less appeal compared to students' writings, giving the native speaker's writing a personal tone (p. 38).

\section{Conclusion and recommendations}

Textual coherence is determined by the logical and appropriate choice of theme (Park \& Nam, 2015). Many students in their writing encounter problems in choosing appropriate themes of their clauses. (Ridah, 2014) and accordingly, they fail to manage the flow of ideas within their written texts and this ultimately decreases the coherence element in their writing. Taking that into consideration, the current study aimed to investigate the frequency of use of the different variants of themes; topical, textual, interpersonal, simple, multiple, marked and unmarked themes. To fulfill the purpose of the study, a number of essays from the students' corpus, in the department of English at the University of Sirte, were analyzed.

In the light of the study results, it is obvious that the students relied heavily on topical themes, particularly, the unmarked type. This dominance in the students' writings gives an indication of the simple structure of students' compositions (Ebrahimi, 2016). Such result reminds us of how important is to raise students' awareness of the significant role of theme variations in writing and the function that each type plays in the overall discourse. Besides, the students need to know how to maintain the appropriate balance between the different types of theme in a way that contributes positively to the development of their writing skill. Further, Ebrahimi (2016) highlighted that "knowledge of the successful balance of theme types and patterns and their functions in different texts could guide readers through the logical path constructed by the writer and result in better comprehension of the text" (p. 112).

The results of the study suggest that teachers need to consider the issue of theme selection through providing explicit instruction for the 
students. Teachers need to go beyond the role of telling and wishing their students to write in a logical manner to showing students how to logically produce coherent text with concrete examples of themes (Park, \& Nam, 2015).

However, the results of the study open channels for future research. Variables such as comparing students' theme selection in different genre of writing can be worth discovering. Besides, researchers can investigate the relations between theme choices and the students' level of proficiency. 


\section{References}

Adawiyah, R. A. (2017). An analysis of theme-rheme organization on academic essay written by the fifth semester students of Uin Raden Fatah Palembang. [SKRIPSI] (Doctoral dissertation.

Arunsirot, S. (2013). An analysis of textual metafunction in Thai EFL students' writing. Novitas-ROYAL (Research on Youth and Language), 7(2), 160-174.

Belmonte, I. A., \& McCabe-Hidalgo, A. (1998). Theme-rheme patterns in L2 writing. Didáctica, 10, 13-31.

Choo, Y. (2009). Improving coherence in writing through the use of themes in essays written by secondary school form 4 students (Doctoral dissertation, Universiti Teknologi Malaysia).

Ebrahimi, S. (2016). Theme types and patterns in research article abstracts: A cross disciplinary study. International Journal of English Language \& Translation Studies, 4(3), 104-115.

Eggins, S. (2004). Introduction to systemic functional linguistics. A\&C Black.

Fries, P. H. (1995). Themes, methods of development, and texts. In R. Hasan and P.H. Fries( Eds.), On subject and theme: $A$ discourse functional perspective. (pp.317-360). John Benjamins Publishing.

Gunawan, W., \& Aziza, F. (2017). Theme and thematic progression of undergraduate thesis: Investigating meaning making in academic writing. Indonesian Journal of Applied Linguistics, 7(2), 413-424.

Halliday, M. A. (1994). An Introduction to Functional Grammar. London: Arnold.

Halliday, M. A., \& Matthiessen, C. M. I. M. (2004). An Introduction to Functional Grammar. London: Edward Arnold.

Halliday, M. A., \& Matthiessen, C. M. I. M (2014). Halliday's Introduction to Functional Grammar. London: Routledge. Jalilifar, A. (2010a). Thematization in EFL students' composition writing and its relation to academic experience. RELC journal, 41(1), 31-45. 
Jalilifar, A. R. (2010b). The status of theme in applied linguistics articles. The Asian ESP Journal, 6 (2), 7-39.

Jianghong, M., Hairong, W., \& Xiangfeng, C. (2005). The implications and applications of theme-rheme theory to the teaching of EFL reading. CELEA journal, 28 (1). 18-22.

Jing, W. E. I. (2013). Corpus-based research on the development of theme choices in Chinese learners' English speech. Journal of Education and Practice, 4(16). 178188.

Kang, J. (2016). A functional approach to the status of theme and textual development. Theory and Practice in Language Studies, 6(5), 1053-1059.

Le, D. T., \& Wijitsopon, R. (2012). Using theme-rheme to analyze ESL/EFL learners' academic writing. Journal of Arts and Humanities, 9 (2). 1-11.

Nikmah, I. (2010). Thematic organization on news item of the general election campaign 2009 in the Jakarta post (Doctoral dissertation, University of Diponegoro).

Panggabean, C. I. (2011). Functional grammar (an introduction to metafunctional components of language). OKARA: Jurnal Bahasa dan Sastra, 5(1). 45-62.

Park, K., \& Nam, D. (2015). Analysis of thematic structure in L2 writing: A systemic functional perspective. SNU Journal of Education Research. 65-88.

Ridha, N. S. A. (2014). Theme and rheme: types and problems in EFL university students' written texts. Journal of Basra researches for Human Sciences, 39(1), 93-114.

Thompson, G. (2013). Introducing functional grammar. Routledge. UK.

Wang, L. (2007). Theme and rheme in the thematic organization of text: Implications for teaching academic writing. Asian EFL Journal, 9(1), 164-176.

Yuned, R. O. (2016). Thematic progressions of the 2015 teflin Article Abstracts in Applied Linguistics. JOALL (Journal of Applied Linguistics \& Literature), 1(2), 95-115.

Zha, Y. (2019, June). Marked themes in WKU student writing: A systemic functional linguistics-based analysis. $3 \mathrm{rd}$ International Conference on Economics and Management, 325. 18-22. 